\title{
The Ottawa Field-Naturalists' Club Awards for 2002
}

\author{
Irwin M. Brodo, Christine Hanrahan, Beverly McBride, and Sheila Thomson
}

At the Club's Annual Soirée, held 26 April 2003, at St. Basil's Church in Ottawa, awards were once again given to members, and one non-member, who distinguished themselves by accomplishments in the field of natural history and conservation, or by extraordinary activity within the Club.
As is frequently the case, there were no winners for a few of the OFNC awards this year. The following citations for those who did receive an award, however, were read to the members and guests assembled for the event.

\section{Bill Royds - Ottawa Field-Naturalists' Club Member of the Year - 2002}

The Ottawa Field-Naturalists' Club has a long history of active, committed members. Many of its committees have benefited greatly from the participation of volunteers with a particular expertise. The OFNC Conservation Committee, which has been actively working to preserve our natural heritage for more than three decades, continues to attract knowledgeable and committed members such as Bill Royds.

The Conservation Committee is one of the more high-profile committees in the club with its members attending meetings, open houses and most importantly, representing the club on any number of other committees outside of the OFNC. It reflects well on the club when these folks are able to contribute substantially to the work being carried out. One of Bill's biggest contributions, and one of his strengths, is his solid understanding of federal, provincial and municipal legislation. Bill not only has such knowledge at his fingertips, but he keeps abreast of changes and developments, which makes him absolutely invaluable since he can answer any question about almost any piece of legislation and give advice on how it works. Bill is especially knowledgeable about proposed and current municipal legislation for the City of Ottawa, which made him a natural to lead in the preparation of the OFNC Brief for Drafts 1 and 2 of the new Ottawa Official Plan. During 2002 he spent a huge amount of time making sure that the OFNC's views on natural areas preservation were clearly and cogently represented.

Bill is a very enthusiastic naturalist, as anyone who has attended a nature walk with him will attest. It is no doubt this deep appreciation for nature that drives his total commitment to protecting natural areas and the environment. He works exceptionally hard to make a difference wherever and whenever he can and is so involved in so many volunteer activities (in addition to working full time) that many of us wonder whether he has found a magic solution for stretching the 24-hour day. But no ... his wife says he gets by on just four hours sleep per night!

Bill's contributions to the OFNC extend well back before 2002, but during this last year he has been particularly active in serving as the link between the OFNC and the Greenspace Alliance of Canada's Capital (GACC). He joined the Greenspace Alliance shortly after it was formed in October 1997 and quickly became an integral part of that dynamic group, serving as its Vice-chair and currently, as its Co-chair. As webmaster for the GACC's website, Bill is able to ensure an efficient exchange of information, which means that the OFNC and the GACC can cooperate profitably on ideas and issues, as the need arises, to the benefit of both groups.

One exceptionally high-profile project that Bill initiated, and worked hard to gain recognition for, is the "Poet's Pathway." This celebration of Canadian Poets and the landscape they loved will almost certainly be an enduring contribution to the Nation's Capital. Conceived of as a $30 \mathrm{~km}$ U-shaped route from Beechwood Cemetery to Britannia Bay with the Southern Corridor as a focal point, this is now being discussed with the National Capital Commission and the literary community.

Bill's contributions on behalf of the Ottawa FieldNaturalists' Club and the community have been particularly outstanding this year, and he is a fitting recipient of the 2002 Member of the Year Award.

\section{David Hobden - George McGee Service Award for 2002}

This year the Ottawa Field-Naturalists' Club recognizes the contributions of David Hobden with the George McGee Service Award.

For over five years, David has been a very active member of the club's Conservation Committee and the Fletcher Wildlife Garden Committee, dealing with all committee affairs with quiet competence, but always with a glint of humour in his eyes.

Since joining the Fletcher team in 1998 David has served the committee in many ways. Five years ago, David stepped in as Treasurer producing the regular, reliable financial statements committee members rely on to plan their many projects. A few years later, David became chairperson, first in an acting capacity, later assuming full responsibility. Four years ago he took over as Fletcher's liaison with landowner Agriculture Canada. He is currently leading critical negotiations with the Department on the use of the property and building that are at the very foundation of Fletcher Wildlife Garden. He has amassed a team of volunteers with expertise in various aspects of business and contracts to assist him. To quote a committee member, "His patience and perseverance have made our relationship with the Department one of mutual trust and respect."

David is a proven leader and organizer in such diverse tasks as hiring summer staff, developing the Fletcher's longterm plan and representing the Fletcher's interests on the Ottawa Field-Naturalists' Club Council. He continually demonstrates his ability to work together with others, to contribute wisdom and thoughtfulness, and to make well considered, effective decisions.

A lot of business acumen goes into keeping the Fletcher Garden humming along, but David has an artistic side too. Much of the garden's photo collection is David's work, all carefully labelled with name, date, and location. 
David has been an OFNC member since the 1960s but he waited for the blessing of retirement to jump in as a volunteer. When he did, he also joined the Conservation Committee, where he is an active and devoted member, rarely (if ever!) missing a meeting. He attends public fora, prepares briefs and edits and comments on those written by others. One committee member noted, "When David offers a comment at a meeting, everyone listens, because we know it will be thoughtful and thought-provoking. Most importantly, he picks up on things that many of us forget or lose sight of in our haste to make a quick point."
A professional biologist, David received his $\mathrm{PhD}$ in England where he studied the bioaccumulation of trace elements in bivalves. He moved to Canada shortly after completing his studies. He was a biology professor at the University of Ottawa for most of the $60 \mathrm{~s}$. Then, until his retirement, he taught many levels and types of biology courses at Algonquin College. His students were fortunate to benefit from David's many fine qualities and dedication to his profession, just as his OFNC colleagues are now benefiting from these same qualities and dedicated volunteer service to the Club.

\section{Philip Fry - Conservation Award for Members - 2002}

Habitat destruction is a modern environmental problem that concerns many of us. Most people deal with it by joining environmental organizations like the Ottawa Field-Naturalists' Club and petition our governments to establish parks, spare woodlots and protect wetlands on the lands they manage. Philip Fry has taken a more direct approach. In 1984, he purchased six hectares of abandoned farmland near Oxford Mills and established a refuge for orphaned and threatened wild plants, calling it "The Old Field Garden." Philip was dismayed at the number of wildflowers, many of them rare, that succumb to the bulldozer, and so, although in his day job he was a professor of art history at the University of Ottawa and not a conservation biologist or horticulturist, he set about rescuing as many of these threatened plants as he could.

On his property, he studied the soils, water conditions and topography and meticulously drew up a plan of his land. He thinned cedar stands, dug ponds and added to the forest loam in order to develop as natural a community of native plants as he could, starting with thousands of plants rescued from land about to be destroyed by development. So successful was his approach that other wild plants of the region (not to mention scores of animals) took up residence at the Old Field Garden without any intervention. The successful rehabilitation of this unused farmland is a model for others, and people come from far and wide to see what he has done and how they can accomplish the same thing with their own property, or parts of it.

Philip's techniques for wildflower propagation and establishment developed by careful experimentation over the past 18 years are now shared with the general public through educational workshops and tours of the Garden, and the products of this propagation are now available for all who are interested in establishing wildflower gardens.

The Ottawa Field-Naturalists' Club recognizes Philip Fry's outstanding contribution to the conservation of native plants and re-establishment of wildlife habitat on abandoned lands in southern Ontario, by awarding him this year's Conservation Award for Members.

\section{Michèle André-St. Cyr - Conservation Award for Non-Members - 2002}

Many people by now have probably seen the "Turtle Crossing" signs at various locations in the Ottawa region, including at Britannia. These signs are the result of the work of one woman, Michèle André-St. Cyr of Rockland. Michèle's story is an inspiring one for it shows what one individual can do when motivated by a desire to bring about change.

While many people are concerned about protecting wildlife, few of us really translate that concern into action. Michèle André-St. Cyr is someone who did. Some years ago, concerned about the high number of turtles she was finding dead on the roads, she decided to do something about the problem. After much thought and discussion she produced a creative yet simple solution: Place "Turtle Crossing" signs at known turtle crossing sites along major roads. Much research and analysis went into their design and the result is a diamond-shaped yellow sign showing a black turtle with tire tracks on its back and black lettering in French and English indicating the months when turtles are most likely to be on the move: May-June.

In 2000, with design in hand, Michèle then got busy writing letters, contacting other knowledgeable people, and making presentations to the (then) City of Cumberland. The City, moved by her initiative and determination, agreed to the erection of these signs, provided she came up with the funding. Undaunted, Michèle set about seeking donations and along with money from her own pocket, had soon acquired the necessary funding to place the signs. That first year 14 signs were placed on local roads. Plans were soon underway to convince the new City of Ottawa to permit similar signs throughout the area and this is now being done.
As word of her work spreads, Michèle is now being contacted by interested individuals and communities from across the province, looking for advice on how they too might follow her lead. As of March 2003, numerous municipalities in Ontario have adopted her idea and her design, and interest has been expressed from outside Ontario.

Not content to rest once the signs had become a reality, Michèle formed the group TURTLE S.H.E.L.L./TORTUE S.H.E.L.L, of which she is current President. Their mandate is to educate and train "teachers, students, public officials and other members of the general public" about the life and ecology of Ontario turtles and instill respect for these creatures. They have produced a well-written and informative booklet in both French and English called Let's Talk Turtles! which provides answers to questions such as: "Why should we care about turtles?", "How many eggs does a turtle lay?", "Why do turtles cross roads and highways?". Michèle's newest idea is to see TURTLE S.H.E.L.L establish a turtle rehabilitation facility to help injured turtles return to the wild. The group also plans to instruct interested people in turtle rescue.

Michèle's enthusiasm, passion, dedication and energy are clearly infectious. It takes a remarkable person to see a problem, take action and find a solution. She singlehandedly rounded up experts in the field, rallied community support and convinced politicians to have a heart. How many individuals have accomplished so much? Michèle has helped make the area that much safer for the gentle, slow-moving and very vulnerable turtle. 